DOI 10.18551/rjoas.2021-10.16

\title{
THE CONTRIBUTION OF THE AGRICULTURE SECTOR TO INCREASING GRDP IN WONDAMA BAY DISTRICT OF INDONESIA
}

\author{
Aninam Johny*, Orisu Lillyani M., Embordin \\ Faculty of Economics and Business, University of Papua Manokwari, Indonesia \\ *E-mail: johnyaninam@yahoo.co.id
}

\begin{abstract}
This study aims to determine how big the contribution of the agricultural sector to the increase in Gross Regional Domestic Product in Teluk Wondama Regency. The analytical method used is the Contribution Method, which is to find out how much contribution can be made from the agricultural sector in Teluk Wondama Regency to the Gross Regional Domestic Product (BPDR), based on data provided by the Central Statistics Agency (BPS) of Teluk Wondama Regency and West Papua Province. The data analysis method in this study uses the Location Quantient (LQ), Shift-Share (SS) approach and Klassen typology. Location Quotien (LQ) An approach used to measure the performance of a region's economic base, Shift Share (SS) Used to analyze changes in the economic structure of a higher region as a comparison (provincial/national) and Klassen's Typology to see an economic sector can be classified into developed, developed but depressed, developing and relatively lagging sectors. Based on the results of the research and the results of data analysis, it can be concluded that the contribution of the agricultural sector to the Gross Regional Domestic Product (GRDP) in 2013, the contribution of the agricultural sector to get a contribution of $67.30 \%$, in this case the figure is quite good in the contribution of GRDP in Teluk Regency. Wondama, while in 2014 there was a decrease in the contribution of the agricultural sector by $63.17 \%$ this figure was a decrease in value from the previous year, for 2015 it again experienced a significant decline in value of 47.54\% while in 2016 the contribution of agriculture increased by $99,96 \%$ where this figure is a very good value in terms of achievement in 2016, for 2017 the contribution of the agricultural sector has decreased quite badly by $33.55 \%$ where this value is a figure that is less for the contribution of the agricultural sector in 2017 and in 2018 again experienced increased contribution by $83,70 \%$ is a pretty good number in 2018.
\end{abstract}

\section{KEY WORDS}

Agriculture sector, GRDP, economy, development.

Regional economic development is a process in which the Regional Government and the community manage all existing resources, by establishing partnership patterns between the Regional Government and the private sector for job creation, and can stimulate economic growth in the region concerned (Suparmoko, 2012).

In the Regional Planning Process, function analysis is an effective tool to see the general frameworks as mentioned above, and can effectively be used to view and as an instrument of community economic activities that are concentrated in a certain area in the development area environment, so as to facilitate the development of the community. the designer to determine the priorities that encourage the community to obtain service facilities easily.

The success of regional economic development is largely determined by development targets based on efforts to increase economic growth that is able to create employment opportunities optimally in terms of quantity, productivity and efficiency. In determining policy, it must take into account internal conditions as well as external developments. The difference between internal and external conditions is only in the reach of an area, where internal conditions cover the national area. Economic improvement is not only carried out by the central government, but local governments also seek these improvements, both macro and micro improvements. 
The agricultural sector has contributed to development, especially in the Wondama Bay Area, regional economic development is closely related to industrialization and the role of the agricultural sector has begun to be replaced by the industrial sector. Regional economic development aims to increase the number and types of job opportunities for local communities. The benchmark for the success of regional economic development can be seen from economic growth and economic structure.

The economic growth of a region is one of the main elements in regional development, although the development process is not only determined by the economic aspect. To date, high economic growth is the main target of development in the regional development plan, through high regional economic growth it is hoped that the welfare of the community can be gradually improved. The ability of the region to grow cannot be separated from the role of the existing sectors in an economy.

Synergy between economic sectors is very important in forming a strong economic structure. A strong synergy between the agricultural, industrial and service sectors will form an efficient economy, and this will also encourage regional economic growth (Sjafrizal, 2008). The greater the contribution given by each economic sector to the GRDP of a region, the economic growth will go in a better direction.

The development of GRDP from 2000 (as the base year) to 2013 shows that in 2009 the GRDP of Teluk Wondama Regency at current prices was Rp. 367.72 billion while in 2013 that figure has reached $R p 566.81$ billion. So over a period of 13 years (2000-2013) the PDRB of Teluk Wondama Regency at current prices has grown by 7.85 times and on the basis of constant 2000 prices it has grown by 3.09 times, namely from the figure of Rp. 72.17 billion in 2000 to a figure of Rp. 222.84 billion in 2013.

In GRDP there are several sectors which are broken down from the primary sector consisting of; agriculture, mining and quarrying, the secondary sector consisting of; processing industry, electricity and drinking water, and buildings, as well as from the tertiary sector consisting of; trade, hotels and restaurants, transportation and communications, finance, rental \& services, and services. GRDP is dominated by the primary sector with a GRDP of $312,206.91$ billion in 2013, and the primary sector itself is the largest contributor to the agricultural subsector which has an income of 308,262.34 billion.

In order to carry out the functions and authorities of local governments in the form of implementing fiscal authority, each region must be able to recognize its potential and identify its resources. Local governments are expected to be better able to explore financial sources, especially to meet government and development financing needs in their regions.

The increase in GRDP continues to occur due to increased output from various business fields. One of the business fields that has experienced a significant increase is the agricultural sector. The agricultural sector, in 2009-2013, made a major contribution to the GRDP of Teluk Wondama district, ranking first from other sectors.

The economic structure can provide an overview of each sector in the formation of the total GRDP in a region. The greater the percentage of a sector, the greater the influence of that sector in the regional economy. The structure in Teluk Wondama Regency is still dominated by the agricultural sector. Based on the above background, the researcher wants to take the title of the research, namely, "The Contribution of the Agricultural Sector to the Increase in Gross Regional Domestic Product (GRDP) in Teluk Wondama Regency".

\section{THEORETICAL REVIEW}

Contribution. For ordinary people, they may not really understand what is meant by the contribution itself theoretically. Ordinary people interpret contribution as contribution or role, or participation of a person in a particular activity. There are many definitions of contributions in a particular activity; there are many definitions of contributions from various experts. They interpret the contribution according to their respective points of view. Maybe some of you have heard the phrase "in carrying out development in the area, the community must contribute to village development" the word contribution here is defined as the involvement of the community in the form of energy, thoughts and concern for a program or activity carried 
out by certain parties. Contributions cannot be interpreted only as a person's participation in legal formalities, but there must be real evidence or concrete actions that the person or group helped to make a particular activity a success. Individuals or groups can contribute their thoughts, energy, and materials for the success of the planned activities to achieve common goals.

Contribution according to the scientific dictionary by Dany $H$. (1998) defines contribution as support in the form of money or support, even in that sense interprets contribution into a much narrower scope, namely contribution as a form of assistance issued by individuals or groups in the form of money only. or financial support. In line with Dany $\mathrm{H}$. Yandianto (2010) in the Indonesian Dictionary defines contribution as a form of contribution of money or funds to a forum, association and so on. So it can be concluded based on the two understandings above that the contribution is a form of real assistance in the form of money for a certain activity to achieve a predetermined common goal.

GRDP Concept and Economic Growth. One indicator to measure the level of regional development is Gross Domestic Product (GDP), in this case the increase in the production of goods and services in Gross Domestic Product. The value stated in the GDP reflects the standard of living and the level of economic development of the community.

In calculating the Gross Regional Domestic Product (GDP) a more realistic approach is needed. However, so far, it still refers to the national calculation model, namely the Gross Domestic Product (GDP) which in the real calculation is economic growth related to the increase in output per capita (Boediono; 1985). There is clearly a side that needs to be considered, namely the total output side and the population side. So the process of increasing per capita output cannot and should not be analyzed by looking at what happens to per capita output and cannot and should not be analyzed by looking at what happens to the total output on the one hand and the population on the other. A complete economic theory must be able to explain what happens to the population.

From this definition, in the regional economic concept, the limits of the Gross Regional Domestic Product must be seen. It's just that it needs to be understood that the regional economy is in a more open position than the national economy.

Gross Regional Domestic Product. Gross Regional Domestic Product (GRDP) is one indicator of the economic growth of a particular region. According to BPS Kabupaten Teluk Wondama (2011), Gross Regional Domestic Product is statistical data presented in series to provide an overview of macroeconomic performance from time to time. So that the direction of the regional economy will be clearer, and can provide benefits for various purposes such as planning, evaluation, and economic development studies.

Basically, economic development is a series of efforts to increase people's income, expand employment opportunities, equitable distribution of income, improve economic relations between regions/regions and seek to shift economic activity from the primary sector, namely sectors that depend on the type of agricultural and mining business fields. and disbursement to the secondary sector (business fields of processing, electricity, gas, and drinking water, construction/building) and tertiary sectors (business, trade, hotels and restaurants, transportation and communications, banks/financial institutions, rental companies, government services and private services).

The calculation of GRDP uses two kinds of prices, namely GRDP at the prevailing price, which describes the added value of goods and services which is calculated using the annual price. In addition, there is GRDP at constant prices, which describes the added value of goods and services which is calculated using prices in one particular year as the base year for the calculation. The GRDP to be analyzed is the GRDP of Teluk Wondama Regency based on constant 2000 prices according to the business field.

Economic growth. According to Schumpeter, economic growth is the natural addition of the rate of population growth and the rate of saving. Meanwhile, according to Putong (2003) economic growth is a significant increase in national income (with an increase in per capita income) in a certain calculation period.

If we talk about economic growth, it is definitely different from economic development. Economic growth is one indicator of the success of development. The higher the economic 
growth, the higher the welfare of the people outside of other indicators. The benefit of economic growth itself is to measure economic progress as a result of national development and regional development (Putong, 2003).

According to Tarigan (2005), regional economic growth is the increase in people's income that occurs in an area which is illustrated by the increase in all added value that occurs in the region. This will also later describe the prosperity of the area. The prosperity of a region is also determined by how large the share of income that flows outside the region or receives a flow of funds from outside the region. Each country will always target a high rate of economic growth in each region, because it describes the prosperity in the region.

W. W Rostow in Adisasmita (2008) puts forward a theory that divides economic growth into several stages, namely the traditional society, the preconditions for take off, the take off, and the movement towards maturity (the drive to maturity) and the age of high mass consumption. The explanation of Rostow's growth is described in Arsyad (1999).

Economic Development. According to Suryana (2000) the efforts that are being actively carried out by developing countries in the world are generally oriented to how to improve or raise the level of living of the people in these countries so that they can live like people in other countries. Developed countries. Economic development is one answer that seems to be a kind of key to the success of a country to improve the standard of living of its citizens.

Efficient economic development requires balanced careful planning of public and private sector resources. Farmers, small entrepreneurs, cooperatives, large entrepreneurs and social organizations should have a role in the planning process. Through regional economic development planning, a region is seen as a whole as an economic unit (Economic Entity) in which there are various elements that interact with each other (Arsyad, 1999).

Economic growth and development are two concepts that cannot be separated. Development is intended to determine sustainable development efforts and does not eliminate the original source, when the theory and the resulting growth model are used as guidelines and the basis of the state. The concept of development is discussed in the theory of growth and development and analyzed by looking at its suitability in the context of the country. Although not all theories or models can be used, regarding the role of expenditure factors including labor, land, capital, and entrepreneurs, it is possible to explain the reasons for the absence of development in a country. At the initial stage, per capita income became the main measure of development. However, through the changing times, aspects of human development and natural development are increasingly emphasized. Development looks at aspects of future generations through the present. It is assumed that the concepts of development and growth are not interpreted from a purely economic perspective but are also inferred from various disciplines such as education and industry (Idris, 2000 in Dewi 2008).

Agriculture. The agricultural sector is one of the primary sectors that provides basic materials (production goods) and direct consumption goods (foodstuffs). Agriculture is not just planting rice and gardening. Agriculture has a very broad scope, including the fisheries, plantation and forestry sectors, from upstream to downstream activities, converting inputs into outputs in the form of clothing, food, shelter, and a comfortable environment for living things (Mattjik, 2006).

In general, the agricultural sector consists of several sub-sectors such as food crops sub-sector, livestock sub-sector, fishery sub-sector, plantation sub-sector, and forestry subsector. Therefore, the agricultural sector is expected to be able to carry out its role in development, namely: providing food, providing employment opportunities for the community, saving and collecting foreign exchange and providing support for the development of other sectors.

In the regional scope, the management of the agricultural sector in each region does not have to be the same as the management of the agricultural sector at the national level because the management of the agricultural sector must adapt to the conditions of each of these regions. Meanwhile, in the regional scope, especially Teluk Wondama Regency, the agricultural sector is directly managed by the Department of Agriculture.

Agricultural development should prioritize the potential of the region and the capabilities of its people. Comparative advantage in the form of natural resources needs to 
be accompanied by an increase in competitive advantage which is realized through the creation of more professional agricultural human resources. Farming communities, especially disadvantaged farming communities as targets for community empowerment, need to be continuously assisted as farming people who are increasingly advanced, independent, prosperous, and justly. Natural and human resources should be the basis for future agricultural development (Wibowo, 2002).

Hypothesis. In a study, it is very important to use a hypothesis or commonly referred to as a hypothesis which means a provisional guess. So to prove from the problem formulation of this study, the hypothesis of this study is:

$\mathrm{H}_{0}$ : The increase in GRDP in Teluk Wondama Regency is due to the contribution of the agricultural sector.

$\mathrm{H}_{1}$ : The increase in GRDP in Teluk Wondama Regency is due to contributions from other non-agricultural sectors.

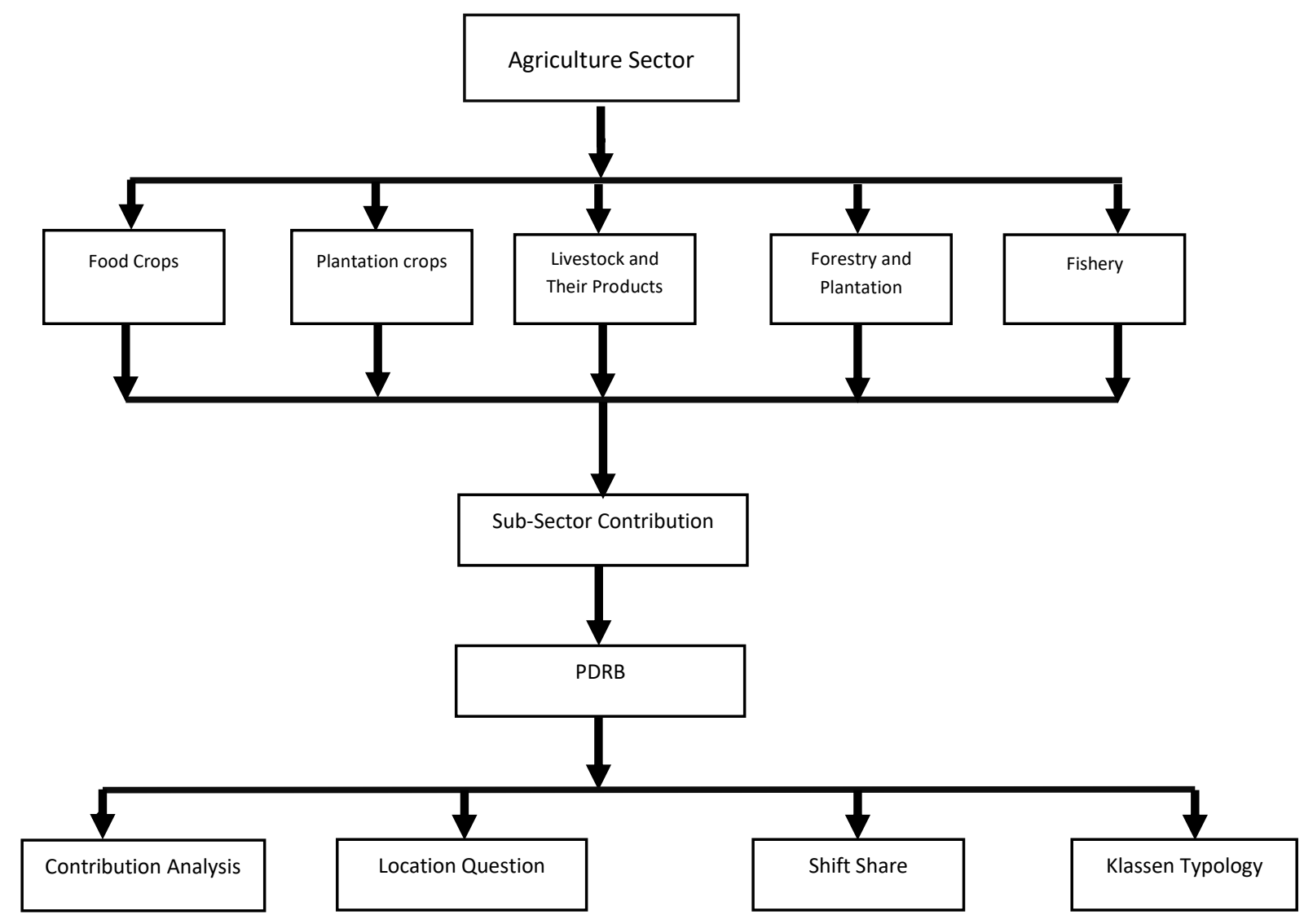

Figure 1 - Thought framework

\section{METHODS OF RESEARCH}

The research location will be conducted in Teluk Wondama Regency, West Papua Province, and the research will be carried out in January 2020. To complete the data and references needed in the preparation of the research proposal, the literature study method is used, namely research used by means of library research from various documents, articles articles and scientific papers related to this writing to obtain secondary data, especially data on GRDP and the agricultural sector in the last five years.

Abdul Halim (2001) to calculate the contribution of the agricultural sector to the Gross Regional Domestic Product in Teluk Wondama Regency, according to Abdul Halim the contribution can be calculated using the following 4 formulas: Sector contribution; Location Quotient (LQ) analysis; Shift Share Analysis; Klassen typology. 


\section{RESULTS AND DISCUSSION}

The agricultural sector is the main source of livelihood for the people of Teluk Wondama Regency. This sector consists of five sub-sectors, namely the Food Crops (Tabama) sub-sector, Plantation Crops Sub-sector, Livestock and other Products Sub-sector, Forestry and Fisheries Sub-sector.

The food crop sub-sector is a staple food crop for the people of Indonesia. This subsector consists of several food commodities such as rice, corn, cassava, sweet potatoes, peanuts, green beans, vegetables, fruits and other staple food crops. The Food Crops Subsector (Tabama) for the last 6 years can be seen in the following table.

Table 1 - Plantation Subsector of Plantation Materials in Teluk Wondama Regency 2013-2018

\begin{tabular}{|c|c|c|c|}
\hline No & Year & Plants Materials for Plantation Millions of Rupiah & percent \% \\
\hline 1 & 2013 & 393.724 .21 & $393,72 \%$ \\
\hline 2 & 2014 & 438.209 .97 & $438,20 \%$ \\
\hline 3 & 2015 & 490.026 .03 & $490,02 \%$ \\
\hline 4 & 2016 & 524.546 .73 & $524,54 \%$ \\
\hline 5 & 2017 & 556.220 .15 & $556,22 \%$ \\
\hline 6 & 2018 & 590.590 .57 & $590,59 \%$ \\
\hline
\end{tabular}

Source: BPS Wondama Bay Regency 2019.

From 2013 to 2018 food crops continued to increase. The increase occurred from RP $393,724.21$ to RP $590,590.57$ in 2018 . The increase occurred because food crops experienced an increase in production and prices.

The plantation sub-sector is a sub-sector consisting of fruits and seeds such as coconut, cocoa, candlenut, secondary crops, pepper, and vanilla. The plantation sub-sector in the 2013-2018 period was not as high as the percentage of the food crops sub-sector. The increase in the plantation sub-sector in the last 6 years can be seen in the table below.

Table 2 - Plantation Subsector in Teluk Wondama Regency 2013 - 2018

\begin{tabular}{|c|c|c|c|}
\hline No & Year & Million Rupiah Plantation & percent \% \\
\hline 1 & 2013 & 473.586 .91 & $473,58 \%$ \\
\hline 2 & 2014 & 485.483 .86 & $485,43 \%$ \\
\hline 3 & 2015 & 521.080 .36 & $521,07 \%$ \\
\hline 4 & 2016 & 577.577 .54 & $577,57 \%$ \\
\hline 5 & 2017 & 610.989 .91 & $610,98 \%$ \\
\hline 6 & 2018 & 638.797 .19 & $638,79 \%$ \\
\hline
\end{tabular}

Source: BPS Wondama Bay Regency 2019.

The table shows that for 2013 to 2018 the plantation sector in Teluk Wondama Regency continues to increase. The increase occurred starting from RP 473,586.91, until 2018 it increased to RP 638,797.19. This increase occurred because plantation yields in Teluk Wondama Regency had increased.

The forestry sub-sector is the sub-sector of wild plants and tall trees. The increase in the forestry sub-sector in the last 6 years can be seen in the table below.

Table 3 - Forestry Sub-sector in Teluk Wondama Regency in 2013-2018

\begin{tabular}{|c|c|c|c|}
\hline No & Year & Forestry millions of Rupiah & percent \% \\
\hline 1 & 2013 & 142.015 .6 & $142,01 \%$ \\
\hline 2 & 2014 & $156,326.74$ & $156,32 \%$ \\
\hline 3 & 2015 & 166.310 .43 & $166,31 \%$ \\
\hline 4 & 2016 & 161.34108 & $161,34 \%$ \\
\hline 5 & 2017 & 170.086 .98 & $170,08 \%$ \\
\hline 6 & 2018 & 185.884 .33 & $185,88 \%$ \\
\hline
\end{tabular}

Source: BPS Wondama Bay Regency 2019. 
In the table from 2013 to 2018 the forestry sector in Teluk Wondama Regency continued to increase. The increase occurred starting in early 2013 an increase of RP $142,015,6$ and in 2018 it increased to RP 185,8843.33. This increase occurred because the sales of the forestry sector in Teluk Wondama Regency experienced an increase.

The forestry sub-sector is food with animal protein content which is very useful for our body. And fish is a commodity that is quite abundant in Teluk Wondama Regency. The increase in the fisheries sub-sector over the last 6 years can be seen in the following table.

Table 4 - Fisheries Subsector of Teluk Wondama Regency 2013-2018

\begin{tabular}{|c|c|c|c|}
\hline No & Year & Millions of Rupiah Fisheries & percent \% \\
\hline 1 & 2013 & 265.477 .32 & $265,47 \%$ \\
\hline 2 & 2014 & 312.326 .50 & $312,32 \%$ \\
\hline 3 & 2015 & 344.711 .01 & $344,71 \%$ \\
\hline 4 & 2016 & 383.282 .51 & $383,28 \%$ \\
\hline 5 & 2017 & 420.801 .97 & $420,80 \%$ \\
\hline 6 & 2018 & 442.9035 .4 & $442,90 \%$ \\
\hline
\end{tabular}

Source: BPS Kabupaten Teluk Wondama 2019.

In the table from 2013 to 2018 the fishery sector in Teluk Wondama Regency continued to increase. The increase occurred in 2013 an increase of RP 265,4773.27 and in 2018 it increased again to RP 442,9035.94. This increase occurred because the abundance of the fishery sector in Teluk Wondama Regency has increased.

Large livestock population in Teluk Wondama Regency Cows, goats, and small livestock populations such as chickens and ducks.

Table 5 - Livestock sub-sector in Teluk Wondama Regency in 2013-2018

\begin{tabular}{|c|c|c|c|}
\hline No & Year & Million Rupiah Farm & percent \% \\
\hline 1 & 2013 & 265.477 .37 & $265,47 \%$ \\
\hline 2 & 2014 & 427.509 .57 & $427,50 \%$ \\
\hline 3 & 2015 & 456.386 .73 & $456,38 \%$ \\
\hline 4 & 2016 & 503.766 .31 & $503,76 \%$ \\
\hline 5 & 2017 & 550.649 .12 & $550,64 \%$ \\
\hline 6 & 2018 & 576.285 .57 & $576,28 \%$ \\
\hline
\end{tabular}

Source: BPS Wondama Bay Regency 2019.

In the table from 2013 to 2018 the livestock sector in Teluk Wondama Regency continues to increase. The increase occurred at the beginning of 2013 an increase of RP 265,477.37 and in 2018 a significant increase returned to RP 576,285.57 This increase occurred because livestock yields were expanding widely in the Wondama Bay Regency which increased.

Table 6 - Agricultural Sector in Teluk Wondama Regency in 2013-2018

\begin{tabular}{|c|c|c|c|}
\hline No & Year & Agriculture sector millions of rupiah & percent \% \\
\hline 1 & 2013 & $509.041,53$ & $509.04 \%$ \\
\hline 2 & 2014 & $534.351,58$ & $534.35 \%$ \\
\hline 3 & 2015 & $548.257,19$ & $548.25 \%$ \\
\hline 4 & 2016 & $559.767,83$ & $559.76 \%$ \\
\hline 5 & 2017 & $588.164,46$ & $588.16 \%$ \\
\hline 6 & 2018 & $605.041,93$ & $605.04 \%$ \\
\hline
\end{tabular}

Source: BPS Wondama Bay Regency 2019.

Of the five sub-sectors above, the plantation sub-sector is the sub-sector with the highest percentage with a value of RP $638,797.19$ compared to other sub-sectors, while the sub-sector that has the lowest percentage is the forestry sub-sector with a value of RP $185,884.33$ this happens because the fisheries sub-sector is not the main source of income for livelihoods of the Wondama Bay Regency community. So the percentage of the forestry 
sub-sector from year to year is always lower than the percentage of other sub-sectors. From the explanation above, we can conclude that the percentage of the agricultural sector for the last 6 years. We can see from the table above that from 2013 to 2018 the agricultural sector continued to increase. This indicates that the economy of Teluk Wondama Regency is still very dependent on the agricultural sector.

One of the indicators to assess the success of a region's development is high economic growth. Economic growth is expected to be able to increase the ability of production factors that stimulate the development of the regional economy on a larger scale in line with government policies after the implementation of district/city regional autonomy since 2013, it is hoped that regional development can further encourage equitable development, and also accelerate development. Economic recovery. Stable economic growth will have an impact on increasing the income of the population which ultimately aims to improve people's welfare.

Income is one of the factors that greatly influences the size of the public saving rate. That is, the greater the amount of income that can be received by the community, the greater the funds that can be collected by the banking sector. Vice versa, if the level of income decreases, the tendency to save is also lower.

The increase that occurs in people's incomes in an area can be seen in the progress of the economy by observing the value of changes in the Gross Domestic Product (GDP) that occur in the area. Gross Regional Domestic Product (GRDP) is divided into two, namely Gross Regional Domestic Product (GRDP) based on constant prices and Gross Regional Domestic Product (GRDP) based on current prices. Gross Regional Domestic Product (GRDP) based on constant prices is the value of goods and services (commodities) ), income and expenses are valued based on fixed (constant) prices.

Due to price changes from year to year, the Gross Regional Domestic Product (GRDP) based on current prices also changes every year. Therefore, Gross Regional Domestic Product (GRDP) based on current prices cannot provide an overview of changes in purchasing power Public. So in this writing, the Gross Regional Domestic Product (GRDP) used is the Gross Regional Domestic Product (GRDP) based on constant prices because the Gross Regional Domestic Product (GRDP) is based on this constant price, we can compare and see how people's purchasing power, level of social welfare and the rate of economic growth. In addition, the Gross Regional Domestic Product (GDP) based on this constant price can also be used for output in different years.

When viewed in terms of income, Gross Regional Domestic Product (GRDP) is called regional income which shows the amount of income (remuneration) received by the community because of their participation in the production process. These incomes include: wages, land rent (rent), interest for capital (interest) and so on.

In this discussion, it will be noted how much economic growth in Teluk Wondama Regency from 2013-2018 where the data used to see economic growth is Gross Regional Domestic Product (GRDP) data on the basis of constant prices for the development of Gross Regional Domestic Product (GRDP) for Teluk Regency. Wondama during the 2013-2018 observation year, continued to experience changes from year to year in line with the development of economic activity after experiencing sluggishness due to a prolonged economic crisis. The development of the Gross Regional Domestic Product (GRDP) in Teluk Wondama Regency in 2013-2018 in general can be seen in the following table.

Table 7 - Development (GDP) of Teluk Wondama Regency in 2013-2018

\begin{tabular}{|c|c|c|}
\hline Year & GRDP (billion Rupiah) & Percentage \% \\
\hline 2013 & 476.942 .34 & $476.94 \%$ \\
\hline 2014 & 502.599 .07 & $502.99 \%$ \\
\hline 2015 & 523.464 .85 & $523.46 \%$ \\
\hline 2016 & 547.112 .82 & $537.11 \%$ \\
\hline 2017 & 569.068 .21 & $569.06 \%$ \\
\hline 2018 & 604.535 .60 & $604.53 \%$ \\
\hline
\end{tabular}

Source: BPS Wondama Bay Regency 2019. 
In the table the development of Gross Domestic Product (GDP) continues to increase where at the beginning of the period in 2013 it was RP 476,942.34. billion rupiah then in the following year, 2014 it increased by $502,599.07$ billion rupiah. In 2015 with a value of RP 523,464.85. Gross Regional Domestic Product (GRDP) has increased, while in 2016 it has increased by RP 547,112.82. In 2017 there was an increase of IDR 569,068.21. Whereas in 2018 it increased by RP 569,068.21.

However, in general, the increase in Gross Regional Domestic Product (GDP) of Teluk Wondama Regency is influenced by the dominant sectors, namely the agricultural, trade, and financial sectors which contribute greatly to economic growth in Teluk Wondama Regency.

The results of the research and discussion are a description of the results obtained in qualitative research. This study also includes data obtained, namely data from the agricultural sector and Gross Regional Domestic Product (GRDP) from 2013-2018. This data was obtained from the Central Statistics Agency (BPS) of Teluk Wondama Regency. Because in this study the agricultural sub-sector and Gross Regional Domestic Product (GRDP) are used.

Table 8 - Contribution of Foodstuff Crops Subsector in Teluk Wondama Regency in 2013-2018

\begin{tabular}{|c|c|c|c|c|}
\hline No & Year & $\begin{array}{c}\text { Plants Materials for Plantation Millions of } \\
\text { Rupiah }\end{array}$ & $\begin{array}{c}\text { Agriculture sector millions of } \\
\text { rupiah }\end{array}$ & Contribution \% \\
\hline 1 & 2013 & 393.724 .21 & 509.041 .53 & $77,34 \%$ \\
\hline 2 & 2014 & 438.209 .97 & 534.351 .58 & $0,80 \%$ \\
\hline 3 & 2015 & 490.026 .03 & 548.257 .19 & $10,15 \%$ \\
\hline 4 & 2016 & 524.546 .73 & 559.767 .83 & $0,93 \%$ \\
\hline 5 & 2017 & 556.220 .15 & 588.164 .46 & $0,94 \%$ \\
\hline 6 & 2018 & 590.590 .57 & 605.0419 .37 & $0.97 \%$ \\
\hline
\end{tabular}

Source: BPS Wondama Bay Regency 2019.

From the table above, we can see that the contribution of the food crops subsector (Tabama) to the agricultural sector in 2013 was 77.34 percent. Meanwhile, in 2014 it decreased by 0.80 percent. In 2015 it increased by $10.15 \%$ while in 2016 it decreased by 0 . $93 \%$. In 2017 it increased by $0.94 \%$, while in 2018 it increased by $0.97 \%$.

Table 9 - Contribution of the Plantation Crops Subsector in Teluk Wondama Regency in 2013-2018

\begin{tabular}{|c|c|c|c|c|}
\hline No & Year & Millions of Rupiah Plantation Plants & Agriculture sector millions of rupiah & Contribution \% \\
\hline 1 & 2013 & 473.586 .91 & 509.041 .53 & $0,93 \%$ \\
\hline 2 & 2014 & 485.483 .86 & 534.351 .56 & $0,83 \%$ \\
\hline 3 & 2015 & 521.080 .36 & 548.257 .10 & $0,99 \%$ \\
\hline 4 & 2016 & 577.577 .54 & 559.767 .83 & $1,03 \%$ \\
\hline 5 & 2017 & 610.989 .91 & 588.164 .44 & $1,03 \%$ \\
\hline 6 & 2018 & 638.797 .19 & 605.041 .97 & $1,05 \%$ \\
\hline
\end{tabular}

Source: BPS Kabupaten Teluk Wondama 2019.

Table 10 - The Contribution of the Livestock Subsector to the Agricultural Sector in Teluk Wondama Regency in 2013-2018

\begin{tabular}{|c|c|c|c|c|}
\hline No & Year & Million Rupiah Farm & Agriculture sector millions of rupiah & Contribution \% \\
\hline 1 & 2013 & 265.477 .37 & 509.041 .53 & $0,52 \%$ \\
\hline 2 & 2014 & 427.509 .57 & 534.351 .56 & $0,80 \%$ \\
\hline 3 & 2015 & 456.386 .73 & 548.257 .10 & $0,83 \%$ \\
\hline 4 & 2016 & 503.766 .31 & 559.767 .83 & $0,90 \%$ \\
\hline 5 & 2017 & 550.649 .12 & 588.164 .44 & $0,93 \%$ \\
\hline 6 & 2018 & 576.285 .57 & 605.041 .97 & $0,95 \%$ \\
\hline
\end{tabular}

Source: BPS Wondama Bay Regency 2019.

The table above illustrates the contribution of the livestock sub-sector to the agricultural sector in 2013 of $0.52 \%$, while in 2014 it increased by $0.80 \%$. In 2015 there was an increase 
of $0.83 \%$, while in 2015 there was a drastic increase of $0.90 \%$. In 2016 again experienced an increase of $0.93 \%$, while in 2018 it continued to increase by $0.95 \%$.

Table 11 - Contribution of the Forestry Subsector to the Agricultural Sector in Teluk Wondama Regency in 2013-2018

\begin{tabular}{|c|c|c|c|c|}
\hline No & Year & Forestry millions of Rupiah & Agriculture sector millions of rupiah & Contribution \% \\
\hline 1 & 2013 & $142.015,6$ & 509.041 .53 & $0.27 \%$ \\
\hline 2 & 2014 & $156,326.74$ & 534.351 .56 & $0,27 \%$ \\
\hline 3 & 2015 & 166.310 .43 & 548.257 .10 & $0 \%$ \\
\hline 4 & 2016 & 161.34108 & 559.767 .83 & $0,28 \%$ \\
\hline 5 & 2017 & 170.086 .98 & 588.164 .44 & $0,28 \%$ \\
\hline 6 & 2018 & 185.884 .33 & 605.041 .97 & $0,30 \%$ \\
\hline
\end{tabular}

Source: BPS Wondama Bay Regency 2019.

From the table and diagram above illustrates that the contribution of the forestry subsector to the agricultural sector in Teluk Wondama Regency in 2013 was $0.27 \%$, while in 2014 it did not increase, which was $0.27 \%$. In 2015 the contribution of the forestry sub-sector decreased drastically by $0.0 \%$, while in 2016 it increased by $0.28 \%$. In 2017 there was no change of $0.28 \%$, while in 2018 there was an increase of $0.30 \%$.

Table 12 - Contribution of the Fisheries Subsector to the Agricultural Sector in Teluk Wondama Regency in 2013-2018

\begin{tabular}{|c|c|c|c|c|}
\hline No & Year & Million Rupiah Fishery & Agriculture sector millions of rupiah & Contribution \% \\
\hline 1 & 2013 & 265.477 .32 & 509.041 .53 & $0,52 \%$ \\
\hline 2 & 2014 & 312.326 .50 & 534.351 .56 & $0,58 \%$ \\
\hline 3 & 2015 & 344.711 .01 & 548.257 .10 & $0,62 \%$ \\
\hline 4 & 2016 & 383.282 .51 & 559.767 .83 & $0,68 \%$ \\
\hline 5 & 2017 & 420.801 .97 & 588.164 .44 & $0,71 \%$ \\
\hline 6 & 2018 & 442.9035 .4 & 605.041 .97 & $0,73 \%$ \\
\hline
\end{tabular}

Source: BPS Wondama Bay Regency 2019.

The table above illustrates that the contribution of the fisheries sub-sector to the agricultural sector in 2013 was $0.52 \%$, while in 2014 it increased by $0.5 \%$. In 2015 it increased by $0.62 \%$ while in 2016 it continued to increase by $0.68 \%$. In 2017 it increased by $0.71 \%$, while in 2018 it continued to increase by $0.73 \%$.

From the results of the contributions in each of the agricultural sub-sectors above, we can conclude that the highest contribution to the agricultural sector is the food crops subsector (Tabama) with an average contribution of RP $43,028,613.53$ or 43.03 percent, while the lowest contribution is the forestry sub-sector with an average contribution of RP 0.545207723 or 0.55 percent, this is because the food crops sub-sector (Tabama) is the source of livelihood for the majority of the people of Teluk Wondama Regency. Meanwhile, the forestry sub-sector is not a source of livelihood for the people of Teluk Wondama Regency.

Table 13 - Contribution of the Agricultural Sector to Gross Regional Domestic Product (GRDP) in Teluk Wondama Regency in 2013-2018

\begin{tabular}{|c|c|c|c|}
\hline No & Year & Agriculture sector GRDP & Contribution \% \\
\hline 1 & 2013 & $673,019.2$ & $67,30 \%$ \\
\hline 2 & 2014 & 631.765 .5 & $63,17 \%$ \\
\hline 3 & 2015 & 473.618 .0 & $47,54 \%$ \\
\hline 4 & 2016 & 969.923 .1 & $96,99 \%$ \\
\hline 5 & 2017 & $335.570,1$ & $33,55 \%$ \\
\hline 6 & 2018 & $837.502,5$ & $80,70 \%$ \\
\hline
\end{tabular}

Source: BPS Wondama Bay District. 
Based on the table of data analysis results, it can be concluded that the contribution of the agricultural sector to Gross Regional Domestic Product (GRDP) in 2013 was $67.30 \%$ while in 2014 there was a decrease of $63.17 \%$, in 2015 it decreased again by 47.54, while in in 2016 it increased by $96.99 \%$, in 2017 it decreased again by $33.55 \%$, in 2018 it increased by $83.70 \%$.

\section{CONCLUSION}

Based on the results of the research and the results of data analysis, it can be concluded that the contribution of the agricultural sector to the Gross Regional Domestic Product (GRDP) in 2013, the contribution of the agricultural sector to get a contribution of $67.30 \%$, in this case the figure is quite good in the contribution of GRDP in Teluk Regency. Wondama, while in 2014 there was a decrease in the contribution of the agricultural sector by $63.17 \%$ this figure was a decrease in value from the previous year, for 2015 it again experienced a significant decline in value of 47.54\% while in 2016 the contribution of agriculture increased by $99,96 \%$ where this figure is a very good value in terms of achievement in 2016, for 2017 the contribution of the agricultural sector has decreased quite badly by $33.55 \%$ where this value is a figure that is less for the contribution of the agricultural sector in 2017 and in 2018 again experienced increased contribution by $83,70 \%$ is a pretty good number in 2018.

By using Location Question Analysis, it can be said that in Teluk Wondama Regency, which is a potential and leading sector, there are two sectors, namely the mining sector and the excavation of electricity and gas procurement, while other sectors are sectors that are not superior but can contribute to GRDP.

The results of the Shift Share analysis of 17 sectors in Teluk Wondama Regency provide a real increase in growth. This indicates that there is an increase in performance in the economic sector. In the economy the highest growth is the agriculture, forestry and fisheries sectors.

The results of Klassen's Typology analysis show that the developed sector and its growth is more rapid in Teluk Wondama Regency has not yet developed, but from the lagging sector in this case it shows that there is a need for increased management in each supporting sector to increase GRDP.

\section{REFERENCES}

1. Arsyad, Lincolin, 1999, Pengantar Perencanaan and Pembangunan Ekonomi Daerah, Edisi Pertama, Yogyakarta: BPFE.

2. Adisasmita, Raharjo 2008. Pengembangan Wilayah Konsep and Teori: Penerbit Graha IImu. Jakarta.

3. Boediono. 1985. Teori Pertumbuhan Ekonomi. Penerbit BPFE: Yogyakarta.

4. Boediono, 2001.Ekonomi Makro, edisi 4, Yogyakarta.

5. Bahrudin, Rudy.2012. Ekonomika Otonomi Daerah. Stim YPKM: Yogyakarta.

6. BPS. 2019: Produk Domestik Regional Bruto Kabupaten Teluk Wondama Menurut Lapangan Usaha 2014-2018. Badan Pusat Statistik. Kabupaten Teluk Wondama.

7. BPS. 2011: Statistik Daerah Kabupaten Teluk Wondama 2010. Badan Pusat Statistik. Kabupaten Teluk Wondama.

8. BPS. 2013: Statistik Daerah Kabupaten Teluk Wondama 2012. Badan Pusat Statistik. Kabupaten Teluk Wondama.

9. BPS. 2014: Statistik Daerah Kabupaten Teluk Wondama 2013. Badan Pusat Statistik. Kabupaten Teluk Wondama.

10. BPS. 2016: Statistik Daerah Kabupaten Teluk Wondama 2015. Badan Pusat Statistik. Kabupaten Teluk Wondama.

11. BPS. (2013): Statistik Daerah Kabupaten Teluk Wondama 2017. Badan Pusat Statistik. Kabupaten Teluk Wondama.

12. Dany, H. Yandianto 2010. Kamus Ilmiah Populer.Surabaya; Gita Media Press. 
13. Halim, Abdul. 2001. Bunga Rampai Manajemen Keuangan Daerah. Yogyakarta. UPPAMP YKPN.

14. Jhingan M.L 2001.Ekonomi pembangunan and perencanaan, PT Graha Grafindo. Persada. Jakarta.

15. Jhigan, M. L. 2014.Ekonomi Pembangunan and Perencanaan. Jakarta: Rajawali Pers.

16. Nazir, Moh. 1988. Metode Penelitian. Jakarta: Ghalia Indonesia.

17. Mattjik, A.A., and Sumertajaya. 2006. Perancangan Percobaan. Jilid 1 Edisi-2 IPB Press: Bogor. 64.

18. Putong, Iskandar. 2003. Pengantar Ekonomi Mikro and Makro, Gahlia. Indonesia.

19. Permendagri Nomor 13 Tahun 2006 Mengenai Klasifikasi Pendapatan Asli Daerah (PAD).

20. Risnawati.2016. Kontribusi Sektor Pertanian Terhadap Produk Domestik Regional Bruto (PDRB) Di Kabupaten Jeneponto.Skripsi.Fakultas Ekonomi and Bisnis Islam. Universitas Islam Negeri Alaudin Makassar: Makassar.

21. Sukirno, 2004, Makroekonomi Teori Pengantar, Edisi Ketiga, Jakarta: Rajawali Pers.

22. Suryana, 2000, Ekonomi Pembangunan: Problematika and Pendekatan, Jakarta: Salemba Empat.

23. Suparmako. 2012. Ekonomi Pembagunan. Edisi kelima.

24. Sjafrizal. 2014. Perencanaan pembangunan daerah dalam era otonomi. Jakarta: PT. Raja Grafindo Persada.

25. Subandi. 2011. Ekonomi Pembangunan, (Cetakan ke 1), Bandung Alfabeta.

26. Tarigan Robinson .2005. Ekonomi Regional: Teori and Aplikasi: Jakarta Bumi Aksara.

27. Yosep J. 2007. Konribusi Sektor Pertanian Terhadap Pendapatan Asli Daerah (PAD) Studi Kasus Pada Pemerintah Kabupaten Klaten.Skripsi. Fakultas Ekonomi. Universitas Sanata Dharma: Yogyakarta.

28. Undang-Undang No. 33 Tahun 2004 Pasal 1 ayat 5,8,9,10 Mengenai Otonomi Daerah.

29. Undang-undang nomor 22 tahun 1999. Tentang penerimaan yang diperolehdaerah dari sumber-sumber dalam wilayahnya sendiri yang dipungut berdasarkan peraturan perundang-undangan yang berlaku.

30. Undang-undang nomor 25 tahun 1999. Tentang perimbangan keuangan antara pusat and daerah.

31. Wibowa A., 2002. Sistem Informasi Menajemen. AMP JKPM. Yogyakarta. 